\title{
Role of hydrophobicity in food peptide functionality and bioactivity
}

\author{
Caleb Acquah" ${ }^{\#}$ Elisa Di Stefano ${ }^{\#}$ and Chibuike C. Udenigwe* \\ School of Nutrition Sciences, University of Ottawa, Ottawa, Ontario, K1N 6N5, Canada \\ \#These authors contributed equally. \\ ${ }^{*}$ Corresponding author: Chibuike C. Udenigwe, School of Nutrition Sciences, University of Ottawa, Ottawa, Ontario, Canada, K1N 6N5. \\ E-mail: cudenigw@uottawa.ca \\ DOI: $10.31665 /$ JFB.2018.4164 \\ Received: November 23, 2018; Revised received \& accepted: December 10, 2018 \\ Citation: Acquah, C., Di Stefano, E., and Udenigwe, C.C. (2018). Role of hydrophobicity in food peptide functionality and bioactivity. J. \\ Food Bioact. 4: 88-98.

\begin{abstract}
Peptides are important compounds used in the development of functional biomaterials, functional foods and nutraceuticals. The functional and bioactive properties of peptides are directly linked to their structural features, including molecular size, presence or absence of charges, amino acid sequence, hydrophobicity, and hydrophilicity. The role of peptide structures in their bioactivities and functionalities is still emerging. Some bioactive peptides have undesirable taste, which can influence consumer interests in novel peptide-based food applications. In this review, we discussed the role of peptide hydrophobicity in their bioavailability, bioactivity, bitterness property, emulsion stability, aggregation and self-assembly for application in novel food formulations and nutraceutical/ drug delivery.
\end{abstract}

Keywords: Bioactive Peptides; Structure; Hydrophobicity; Functionality; Bioactivity; Self-assembly; Bioavailability; Bitter taste.

\section{Introduction}

Research advances over the years have led to the development of several mainstream compounds for the treatment of diseases and for maintaining physiological homeostasis. However, the side-effects of some compounds can be burdensome (Fekete et al., 2015). Bioactive peptides have demonstrated several health-promoting effects that can be the basis of formulation of functional foods and nutraceuticals. This beneficial property has attracted the interest of consumers, food scientists, health professionals, and the food industry. Examples of physiological benefits derived from bioactive peptides include antioxidant, antihypertensive, antimicrobial, anti-inflammatory, anticalmodulin, anticancer, antithrombotic, and mineral binding activities (Agyei et al., 2017; Udenigwe 2014). The peptides discussed in this contribution are low molecular weight compounds generated via hydrolysis of food proteins by digestive, microbial, or plant proteases; in some cases, post-hydrolysis processes are used to isolate the active or functional molecules present in the complex hydrolysate mixture (Udenigwe and Aluko 2012).

The functional and bioactive properties of peptides are predi- cated on their structural features. The peptide structure encompasses properties such as molecular weight, net charge, amino acid sequence, hydrophobicity, and hydrophilicity. The type of enzyme used for proteolysis, the degree of hydrolysis, and processing conditions are known to influence the structure of peptides generated from proteins, which in turn affects the functional property, bitterness, biostability, cellular uptake, bioavailability, and bioactivity of peptides (Xie et al., 2015; Udenigwe and Aluko, 2012). Typically, the structure of food-derived bioactive peptides contains 2-20 amino acid residues, and is often predominated by hydrophobic chemical groups (Rani et al., 2018; Sánchez and Vázquez, 2017). Notably, the aforementioned structural features may act synergistically to promote the functionality and bioactivity of peptides (Yao et al., 2018). There is emerging interest in understanding the structure-property relationship of bioactive or functional peptides. This type of information is crucial in the design of potent or functionally useful peptides and in understanding their interaction with the food product and biological matrices. This contribution discusses the extant literature on the specific role of hydrophobicity in several functionalities and bioactivities of food protein-derived peptides. 


\section{Hydrophobicity of peptides}

Protein hydrolysis results in changes in the globular structure of the cleaved fragments, exposing amino acids of the hydrophobic regions, such as Phe, Tyr, Trp and Leu, which are typically hidden within the interior of the native protein structure (Al-Shamsi et al., 2017). Hydrophobicity plays a vital role in many functional and bioactive properties of food-derived peptides, as shown in Figure 1. For instance, the presence of aromatic amino acid residues at the $\mathrm{C}$-terminus and hydrophobic amino acid residues at the N-terminus enhance the activity of peptides in inhibiting angiotensin I-converting enzyme (ACE) activity (Cheung et al., 2009; Majumder and Wu, 2009). Moreover, Xie et al., (2015) suggested that the hydrophobicity of casein-derived peptides could enhance their bioavailability and antioxidant properties, although a low digestive stability of the peptides was observed in simulated gastrointestinal fluids. Hydrophobic amino acids are also known to play a vital role in imparting a bitter taste to peptides (Seo et al., 2007). Owing to the importance of hydrophobicity in understanding the structure-property relationship, several amino acid hydrophobicity scales have been developed over the years. Table 1 shows the hydrophobicity scores of the 20 proteinogenic amino acids based on five hydrophobicity scales, with the Kyte and Doolittle scale being the most utilised in the literature. Hydrophobicity of peptide sequences can be calculated based on hydrophobicity of amino acid sidechains, using open access web-based bioinformatic tools (Table 2).

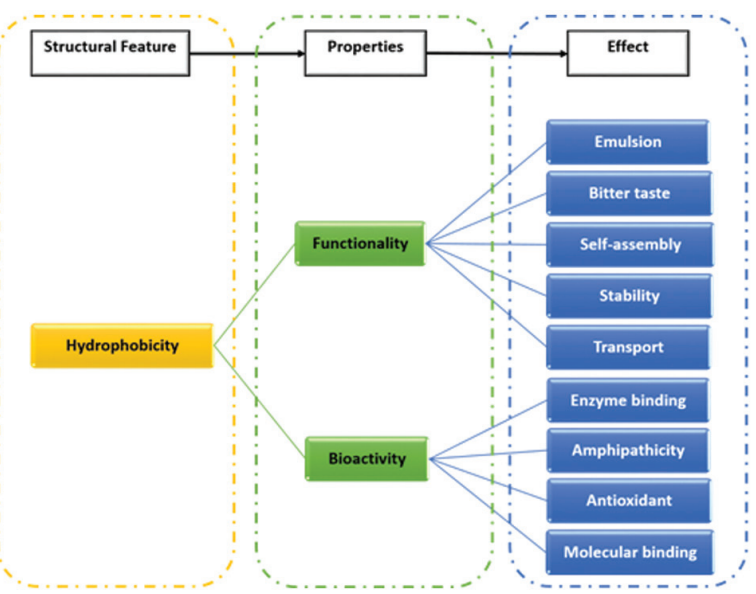

Figure 1. Role of hydrophobicity in several functionalities and healthrelated bioactivities of food protein-derived peptides.

3. Role of hydrophobicity in peptide functionality

\subsection{Emulsion stability}

Emulsions can exist in different forms including oil-in-water, wa-

Table 1. Amino acid hydrophobicity scales

\begin{tabular}{|c|c|c|c|c|c|c|c|}
\hline \multirow[b]{2}{*}{ Amino acid } & \multirow[b]{2}{*}{ Symbol } & \multicolumn{6}{|c|}{ Hydrophobicity Scale } \\
\hline & & $\begin{array}{l}\text { Kyte and Doolit- } \\
\text { tle (1982) }\end{array}$ & $\begin{array}{l}\text { Eisenberg et } \\
\text { al. (1984) }\end{array}$ & $\begin{array}{l}\text { Wolfenden } \\
\text { et al. (1983) }\end{array}$ & $\begin{array}{l}\text { Cornette et } \\
\text { al. (1987) }\end{array}$ & $\begin{array}{l}\text { Wimley and } \\
\text { White (1996) }\end{array}$ & $\begin{array}{l}\text { Hopp and } \\
\text { Woods (1983) }\end{array}$ \\
\hline Isoleucine & Ile (I) & 4.50 & 1.38 & 0.88 & 4.80 & 0.31 & -1.80 \\
\hline Valine & Val (V) & 4.20 & 1.08 & 0.86 & 4.70 & -0.07 & -1.50 \\
\hline Leucine & Leu (L) & 3.80 & 1.06 & 0.85 & 5.70 & 0.56 & -1.80 \\
\hline Phenylalanine & Phe (F) & 2.80 & 1.19 & 0.88 & 4.40 & 1.13 & -2.50 \\
\hline Cysteine & Cys (C) & 2.50 & 0.29 & 0.91 & 4.10 & 0.24 & -1.00 \\
\hline Methionine & Met (M) & 1.90 & 0.64 & 0.85 & 4.20 & 0.23 & -1.30 \\
\hline Alanine & Ala (A) & 1.80 & 0.62 & 0.74 & 0.20 & -0.17 & -0.50 \\
\hline Glycine & Gly (G) & -0.40 & 0.48 & 0.72 & 0.00 & -0.01 & 0.00 \\
\hline Threonine & $\operatorname{Thr}(\mathrm{T})$ & -0.70 & -0.05 & 0.70 & -1.90 & -0.14 & -0.40 \\
\hline Serine & $\operatorname{Ser}(S)$ & -0.80 & -0.18 & 0.66 & -0.50 & -0.13 & 0.30 \\
\hline Tryptophan & $\operatorname{Trp}(\mathrm{W})$ & -0.90 & 0.81 & 0.85 & 1.00 & 1.85 & -3.40 \\
\hline Tyrosine & $\operatorname{Tyr}(\mathrm{Y})$ & -1.30 & 0.26 & 0.76 & 3.20 & 0.94 & -2.30 \\
\hline Proline & Pro (P) & -1.60 & 0.12 & 0.64 & -2.20 & -0.45 & 0.00 \\
\hline Histidine & His $(H)$ & -3.20 & -0.40 & 0.78 & 0.50 & -0.96 & -0.50 \\
\hline Glutamic acid & Glu (E) & -3.50 & -0.74 & 0.62 & -1.80 & -2.02 & 3.00 \\
\hline Glutamine & $\mathrm{Gln}(\mathrm{Q})$ & -3.50 & -0.85 & 0.62 & -2.80 & -0.58 & 0.20 \\
\hline Aspartic acid & Asp (D) & -3.50 & -0.90 & 0.62 & -3.10 & -1.23 & 3.00 \\
\hline Asparagine & Asn (N) & -3.50 & -0.78 & 0.63 & -0.50 & -0.42 & 0.20 \\
\hline Lysine & Lys (K) & -3.90 & -1.50 & 0.52 & -3.10 & -0.99 & 3.00 \\
\hline Arginine & $\operatorname{Arg}(R)$ & -4.50 & -2.53 & 0.64 & 1.40 & -0.81 & 3.00 \\
\hline
\end{tabular}


Table 2. Bioinformatic tools for calculating the hydrophobicity of peptides

\begin{tabular}{|c|c|c|}
\hline Bioinformatic tools & Platform provider & Website \\
\hline Peptide 2.0 & Peptide 2.0 Inc. & $\begin{array}{l}\text { https://www.peptide2.com/N_peptide_hydrophobicity_ } \\
\text { hydrophilicity.php }\end{array}$ \\
\hline Peptide property tool & Genescript & https://www.genscript.com/tools/peptide-property-calculator \\
\hline Peptide analysing tool & ThermoFisher Scientific & $\begin{array}{l}\text { https://www.thermofisher.com/ca/en/home/life-science/ } \\
\text { protein-biology/peptides-proteins/custom-peptide-synthesis- } \\
\text { services/peptide-analyzing-tool.html }\end{array}$ \\
\hline Peptide property calculator & Biosynthesis & $\begin{array}{l}\text { https://www.biosyn.com/peptidepropertycalculator/ } \\
\text { peptidepropertycalculator.aspx }\end{array}$ \\
\hline PepCalc.com & Innovagen & https://pepcalc.com/ \\
\hline Prot pi peptide tool & Prot pi & https://www.protpi.ch/Calculator/PeptideTool \\
\hline Peptide property calculator & Northwestern University & http://biotools.nubic.northwestern.edu/proteincalc.html \\
\hline PLATINUM & $\begin{array}{l}\text { Laboratory of Biomolecular Modelling, } \\
\text { Russian Academy of Sciences }\end{array}$ & https://model.nmr.ru/platinum/ \\
\hline $\begin{array}{l}\text { Peptide Library Design and } \\
\text { Calculator Tool }\end{array}$ & Millipore Sigma & $\begin{array}{l}\text { https://www.sigmaaldrich.com/technical-documents/articles/ } \\
\text { biology/peptide-library-design-and-calculator-tool.html }\end{array}$ \\
\hline GPMAW lite & Alphalyse Inc. & $\begin{array}{l}\text { https://www.alphalyse.com/customer-support/gpmaw-lite- } \\
\text { bioinformatics-tool/start-gpmaw-lite/ }\end{array}$ \\
\hline R-software & R Core Team & https://www.r-project.org/contributors.html \\
\hline
\end{tabular}

ter-in-oil, multiple emulsions (O-W-O or W-O-W), and nanoemulsions. Proteins have strong emulsion stabilizing effect owing to their high intrinsic surface activity, amphiphilicity, hydrophobicity, and capacity to quickly anchor at the oil-water or water-oil interface (Lam and Nickerson 2013; Al-Shamsi et al., 2018). Strong emulsifiers can stabilize small droplet sizes and this property positively correlates with the surface hydrophobicity of proteins (Chen et al., 2016). Thus, protein hydrolysis can release peptides with exposed hydrophobic regions, which would promote their emulsion stabilizing effect (Figure 2). For instance, Qi et al., (1997) demonstrated that hydrolysis of soy protein isolates with pancreatin resulted in increased surface hydrophobicity and emulsifying capacity when compared to the native soy protein isolates. Notably, modification of proteins by limited hydrolysis leads to a high interfacial activity and thus an initial rapid foaming and emulsifying capacity (Hall et al., 2017). However, the foaming and emulsion stabilizing effect of protein hydrolysates could also decrease over time due to the reduction in molecular size of the polypeptides and changes in hydrophobicity during extensive hydrolysis, which affects the strength of the interfacial layer and formation of networks (Hall et al., 2017; Miñones Conde and Rodríguez Patino, 2007). Modification of proteins by controlling the degree of hydrolysis can result in their structural rearrangement, increase in solubility, reduction of molecular size, exposure of hydrophobic amino acids, and increase in surface hydrophobicity to enhance the emulsifying stabilizing capacity of peptides (Lam and Nickerson, 2013; Tsumura, 2009).

An improvement in emulsifying capacity has also been reported by Chen et al. (2016) after incorporating high-pressure microfluidization pre-treatment prior to hydrolysis of soy protein isolate with pancreatin. It was suggested that high-pressure microfluidization of soy protein isolates resulted in structural rearrangement that enhanced the accessibility of particular subunits, such as $\alpha^{\prime}$ $7 \mathrm{~S}, \mathrm{~A}-11 \mathrm{~S}$ and B-11S, to the enzyme. This resulted in a smaller

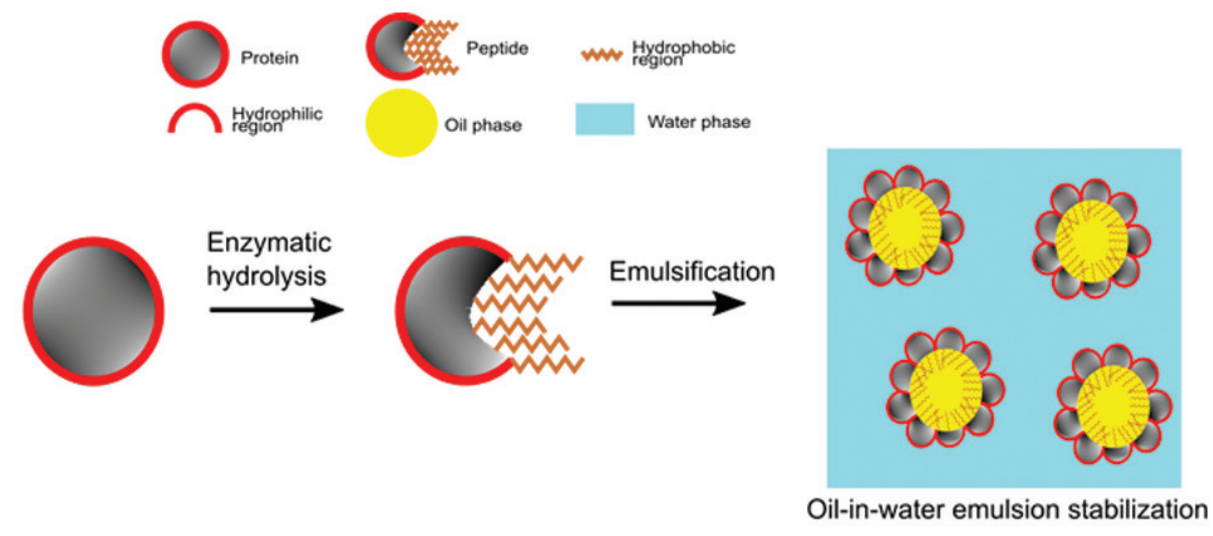

Figure 2. Enzymatic hydrolysis in producing hydrophobic peptides for stabilizing emulsions. 


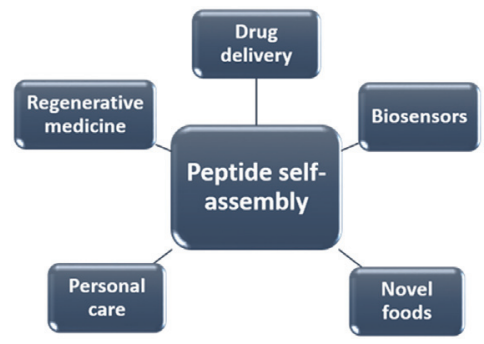

Figure 3. Various applications of peptide self-assembly.

mean droplet size, increased protein solubility, reduced molecular weight, increased surface hydrophobicity, and improved emulsion stability.

\subsection{Self-assembly and aggregation}

Self-assembly is a spontaneous process by which molecular units organise into ordered structures through intermolecular and intramolecular interactions. The spontaneous process is regulated by balancing the attractive and repulsive forces existing between and within the molecules (Mandal et al., 2014). Molecules that undergo self-assembly are generally amphiphilic and thus contain both hydrophobic and hydrophilic moieties. Peptides can be amphiphilic and thus influenced to undergo self-assembly by factors such as concentration, temperature, $\mathrm{pH}$, and ionic strength of their environment. Figure 3 shows several applications of peptide selfassembly. The common motifs involved in peptide self-assembly are the association of $\beta$-strands and $\alpha$-helices (Doll et al., 2013; Deming, 2005). Molecular self-assembly occurs above the critical aggregation concentration of a compound and is thought to be driven mostly by non-covalent forces such as electrostatic interactions, van der Waals, $\pi$-stacking and hydrogen bonding, with the latter being the most influential (Hutchinson et al., 2017). Ganesan and Matysiak (2016) demonstrated that backbone interpeptide dipolar interactions contributed significantly in the aggregation of fibril-like peptides, and that the hydrophobic-hydrophilic interface enhanced the order and rate of aggregation. Moreover, Kim and Hecht (2006) reported that hydrophobic amino acid residues present at the $\mathrm{C}$-terminal of amyloid $\beta$ peptide contributed in triggering aggregation of the peptide. The process of peptide self-assembly and aggregation is complex. Several models have been used to predict aggregation mechanisms due to the lack of suitable experimental techniques to unravel their early formation at the atomic level (Meli et al., 2008).

During assembly, hydrogen bonding existing between backbone structures causes peptide monomers to align longitudinally into $\beta$-sheets. The inter- $\beta$-sheets interactions on the side chains of peptide molecules control the slow, lateral packing of $\beta$-sheets (Zhou et al., 2016). All amino acids, with the exception of glycine, contain a chiral carbon atom in the L configuration. The intrinsic chirality of amino acids causes a twist in the lateral packing of $\beta$-sheets, which affects the final morphology such as nanofibers, nanovesicles, nanomicelles, nanofibrils and nanotubes of the self-assembled peptides (Cui et al., 2009). Notably, the stronger the inter- $\beta$-sheet interactions on the side chains of peptides, the better the lateral packing. Peptides are good candidates for developing self-assembled nanostructures for biological applications due to their structural and functional diversity, and biocomptability (Mandal et al., 2014). Further studies are needed to advance current knowledge in food peptide aggregation and self-assembly, specifically in identifying the driving forces and formation mechanisms, and adapting the peptide products for food and biomedical applications.

\subsection{Biostability and transport across intestinal cells}

Biostability and cellular uptake of peptides are highly influenced by their molecular size, hydrophobicity, and net charge (Chua et al., 2004; Wang and Li, 2017). Although bioactive peptides are susceptible to degradation by gastrointestinal proteases and serum peptidases, numerous in vitro studies in human intestinal (Caco-2) cell monolayers have demonstrated that the transport of some peptides can occur successfully without altering their bioactivities (Fu et al., 2016; Fernández-Tomé et al., 2018; Vij et al., 2016). Resistance to peptidases during intestinal transport is thought to be dependent on the specific peptide and positioning of their amino acid residues (Fu et al., 2016). According to Shimizu et al., (1997), N-terminal amino acid residues are more prone to intestinal peptidase degradation compared to C-terminal residues, and this may influence the bioavailability of peptides in the gut. Ohsawa et al., (2008) suggested that the presence of Pro residues could enhance the resistance of antihypertensive peptides to peptidase activities. The positioning of hydrophobic aromatic amino acids, Tyr, Phe and Trp, at the C-terminal could also enhance the resistance of peptides to intestinal peptidases (Bejjani and $\mathrm{Wu}$ 2013). In a recent study, Yang et al., (2017) demonstrated that the structural stability, transport across Caco-2 cell monolayers and bioactivity of Leu-Tyr, Arg-Ala-Leu-Pro and Thr-Phe may be dependent on hydrophobicity. They found that Thr-Phe was highly prone to human intestinal brush border amino peptidases followed by Arg-Ala-Leu-Pro, whereas hydrophobic Leu-Tyr retained its structural integrity and activity in inhibiting ACE and renin, after peptidase treatment. Furthermore, lipophilicity of peptides (i.e., hydrophobicity and hydrogen bonding potential) is crucial in transcellular intestinal transport of peptides, by facilitating their interaction with cell membranes (Pauletti et al., 1997). Peptide modifications (e.g. cyclization) that increase hydrophobicity and decrease hydrogen bonding potential are considered effective approaches for enhancing oral bioavailability of peptide drugs (Pauletti et al., 1997). Hydrophobicity can also influence the bioaccessibility of peptides in the gastrointestinal tract, but further studies are needed to validate these relationships for food protein-derived peptides.

\subsection{Hydrophobicity-taste relationship}

Factors determining the bitterness of peptides include degree of hydrolysis, processing conditions, type of protease used in protein hydrolysis, average hydrophobicity value, and sequence of hydrophobic amino acid residues (Murray et al., 2018; Seo et al., 2007; Iwaniak et al., 2018). Other factors such as modification by acetylation or esterification of the carboxyl and amino groups could also exacerbate the undesirable organoleptic properties of peptides (Kohl et al., 2012). Bitterness property of functional foods can be evident when there is a disproportionate concentration of bitter peptides amongst other food bioactive constituents. Heinz Ney (1979) demonstrated that peptide bitterness is mainly attributed to the presence of hydrophobic amino acid residues, and proposed the $Q$ rule. The $Q$ value specifies average hydrophobicity based on individual free energies of the amino acid residues, as shown in the following equation: 


$$
Q=\frac{\sum \Delta f}{n}
$$

where $\Delta f$ represents the sum of individual free energies, and " $n$ " is the number of amino acid residues in the peptide. All peptides with $Q$ values less than $1,300 \mathrm{cal} /$ residue were observed to be nonbitter, whereas bitter peptides had $Q$ values of $>1,400 \mathrm{cal} /$ residue. Notably, there was no statistical bitter taste correlation for $Q$ values between 1,300 and 1,400 cal/residue. Despite the ability of the $Q$ rule to predict peptide bitterness based on their average hydrophobicity, this approach is fraught with significant limitations. First, evaluation of bitter taste based on hydrophobicity of peptides was limited to a molecular weight less than 6,000 Da (Heinz Ney, 1979). As such, there are no bitter taste attributes for $Q$ values above this molecular weight threshold. Additionally, lysine and proline have tremendously high $Q$ values, which can lead to false assessment when they are present in non-bitter peptides (Wu and Aluko, 2007). Also, there are reports of bitter peptides containing hydrophilic amino acid residues with low $Q$ values, e.g. aspartic acid and glutamic acid (Ohyama et al., 1988).

Variations in the length of peptide sequence stem from the use of proteases with different specificities in cleaving peptide bonds. Humiski and Aluko (2007) found that Alcalase and Flavourzyme, out of five different proteases, produce more bitter peptides due to their specificity for hydrophobic amino acid residues, whereas papain and $\alpha$-chymotrypsin had the most desirable taste scores. There was no observed correlation between molecular size and bitterness scores of the peptides from pea protein hydrolysates (Humiski and Aluko, 2007). Also, total content of hydrophobic free amino acids, such as Val, Ile, Phe, Trp, Leu and Tyr, were observed to increase with bitterness when Alcalase was used to produce cricket protein hydrolysates (Hall et al., 2017). This finding is in agreement with that of Seo et al. (2007) who observed that Alcalase produced the highest bitter score after soy protein hydrolysis, followed by Neutrase, Protamex, papain, bromelain, and Flavourzyme.

Recently, a chemometric analysis of dipeptides and tripeptides showed that bulky and branched sidechains of Leu, Ile, Val, Tyr, Phe and Trp, when present at the C-terminal, increase the bitterness of peptides (Iwaniak et al., 2018). Using C6-glioma cells that express bitter taste receptor (T2R)1, Upadhyaya et al. (2010) demonstrated that the highly hydrophobic tripeptide Phe-Phe-Phe is capable of activating the receptor based on observed changes in intracellular calcium levels. The role of hydrophobic amino acid residues in bitterness is thought to be related to their binding of the human taste G-protein coupled receptors (GPCR), and activation of associated sensory signalling processes. However, Zhang et al., (2018) recently reported that, although hydrophobicity enabled the bioaccessibility to target organs, two beef-derived peptides, Ala-Gly-Asp-Asp-Ala-Pro-Arg-Ala-Val-Phe and Glu-Thr-SerAla-Arg-His-Leu, suppressed the activation of quinine-dependent T2R4 expressing cells due to their high hydrophilicity $(>50 \%)$. This finding underscores the possible contribution of other structural and environmental factors in determining molecular interactions and biological effects.

\section{Role of hydrophobicity in peptide bioactivity}

\subsection{Enzyme binding and inhibition}

Due to similarity with the structure with human regulatory peptide motifs, several food-derived peptides are able to interact with enzymes and receptors involved in the regulation of inflammatory process, blood glucose level, and blood pressure, such as ACE, dipeptidyl peptidase IV (DPP-IV), renin, and $\alpha$-glucosidase. In many instances, as discussed below, peptide hydrophobicity is thought to play crucial roles in stabilizing these molecular interactions and promoting bioactivity.

\subsubsection{Alpha-glucosidase inhibition}

Alpha $(\alpha)$-glucosidase, a human enzyme located in the epithelial mucosa of the small intestine, is responsible for the hydrolysis and release of terminal, non-reducing glucose moieties from food-derived disaccharides. Due to the enzyme's central role in regulating postprandial glucose release, $\alpha$-glucosidase inhibitors have been developed for type 2 diabetes management. The presence of hydrophobic amino acids Pro, Met and Ala, close to the C-terminal of the peptide, was observed to contribute in promoting the inhibitory activity (Kang et al., 2013; Mojica et al., 2017). Molecular docking studies also revealed that hydrophobic amino acid residues of peptides predominantly interact with residues in the active site of $\alpha$-glucosidase (Mojica and de Mejía, 2016; Di Stefano et al., 2018). In addition, QSAR models of $\alpha$-glucosidase inhibitors have confirmed the importance of molecular hydrophobicity in their bioactivity, and also showed that a balance between hydrophobic and hydrophilic residues is crucial for the formation of $\mathrm{H}$-bonds and electrostatic interactions involved in the enzyme-inhibitor complexation (Moorthy et al., 2011). Besides the involvement of hydrophobic amino acid residues, the mechanisms involved in the $\alpha$-glucosidase inhibitory activity of peptides still need to be elucidated.

\subsubsection{Angiotensin I-converting enzyme inhibition}

The renin-angiotensin system is the major pathway involved in blood pressure control, where renin is responsible for the conversion of angiotensinogen into angiotensin I (rate limiting step), and ACE subsequently converts angiotensin I into the strong vasoconstrictor angiotensin II, while inactivating the vasodilator, bradykinin. Because of its crucial involvement in blood pressure regulation, ACE inhibitors are currently used as drugs for treating hypertension. When considering the ACE inhibitory activity of peptides, the presence of hydrophobic amino acids Pro, Phe, Ile, Val, close to the C-terminus of peptides promotes their binding to $\mathrm{ACE}$ and ultimately intensifies enzyme inhibition (Cheung et al., 1980; Fu et al., 2016). For instance, the most active ACE inhibiting peptides from enzymatic hydrolysis of egg white protein were hydrophobic (Phe-Arg-Ala-Asp-His-Pro-Phe-Leu, $\mathrm{IC}_{50} 3.2 \mu \mathrm{M}$; Tyr-Ala-Glu-Glu-Arg-Tyr-Pro-Ile-Leu, $\mathrm{IC}_{50} 4.7 \mu \mathrm{M}$; and ArgAla-Asp-His-Pro-Phe-Leu, $\mathrm{IC}_{50} 6.2 \mu \mathrm{M}$ ), and that from digested squid skin collagen was a proline-rich decapeptide with an $\mathrm{IC}_{50}$ of $48 \mu \mathrm{M}$ (Miguel et al., 2004; Alemán et al., 2013). ACE inhibiting peptides isolated from digested pork meat (Arg-Pro-Arg and ProThr-Pro-Val-Pro) and from Spanish dry-cured ham (Ala-Ala-AlaThr-Pro) also showed similar hydrophobicity features (Escudero et al., 2012, 2013). The crucial role of hydrophobic amino acids was demonstrated by Saiga et al. (2006) with the ACE inhibitory polypeptide Gly-Phe-Hyp-Gly-Thr-Hyp-Gly-Leu-Hyp-Gly-Phe isolated from digested chicken breast muscle, which had its $\mathrm{IC}_{50}$ value increased (i.e. decrease in activity) from $42 \mu \mathrm{M}$ to $52.5 \mu \mathrm{M}$ by the removal of the $\mathrm{C}$-terminal Phe residue using ACE. Interestingly, other fragments of the peptide with C-terminal Phe (i.e. Hyp-GlyLeu-Hyp-Gly-Phe and Hyp-Gly-Thr-Hyp-Gly-Leu-Hyp-Gly-Phe) exhibited relatively higher ACE inhibitory activities with $\mathrm{IC}_{50}$ 
values of 10 and $19 \mu \mathrm{M}$, respectively. These structure-activity relationships were established based on in vitro studies. It would be beneficial to confirm the role of hydrophobicity in lowering of blood pressure when the bioactive peptides are present in complex food and physiological environments.

\subsubsection{Dipeptidyl peptidase-IV inhibition}

DPP-IV is a metabolic enzyme that selectively converts the incretin hormones, gastric inhibitory peptide and glucagon-like peptide-1, into their inactive forms, thereby largely influencing postprandial insulin release. Because of its detrimental activity towards postprandial glucose regulation, DPP-IV inhibitory drugs called gliptins have been developed as a therapeutic strategy for type 2 diabetes mellitus (Liu et al., 2017). DPP-IV contains a hydrophobic site S1 with Tyr631, Val656, Trp659, Tyr666 and Val711 residues, and a charged site S2 with Arg125, Glu205, Glu206, Phe357, Ser209 and Arg358 residues (Power et al., 2014). Several studies using bioinformatics, in vitro and animal models have demonstrated that food proteins contain DPP-IV inhibiting peptides within their primary structures (Liu et al., 2017; Udenigwe et al., 2013). These peptides can be released using methods such as enzymatic hydrolysis and fermentation. DPP-IV inhibiting compounds exert their bioactivity by interacting with the enzyme active site through salt bridges, hydrophobic interactions, and H-bonds. Notably, the interaction with drug inhibitors mostly occurs at the Arg125, Glu205, Glu206, Tyr547, Tyr662, Tyr666, Ser630 and Phe357 residues of the enzyme, whereas the Glu205, Glu206 and Ser630 residues interact with the N-terminus hydrophobic region of some peptides (Arulmozhiraja et al., 2016). In general, food-derived peptides were observed to interact with both the hydrophobic S1 and charged S2 pockets of DPP-IV. For instance, Liu et al., (2017) reported that DPP-IV inhibiting peptides LAPSTM $\left(\mathrm{IC}_{50} 140 \mu \mathrm{M}\right)$, FAGDDAPR $\left(\mathrm{IC}_{50} 168 \mu \mathrm{M}\right)$ and FAGDDAPRA $\left(\mathrm{IC}_{50} 393 \mu \mathrm{M}\right)$ interacted with regions of the enzyme through $\mathrm{H}$-bonding and $\pi-\pi$ interactions. The presence of hydrophobic amino acids at the N-terminus of peptides is a peculiar feature of identified DPP-IV inhibiting peptides. In addition to hydrophobicity, the penultimate $\mathrm{N}$-terminal position appears to play a crucial role in enhancing or decreasing the bioactivity. Harnedy et al. (2015) reported that the DPP-IV inhibitory activity of peptides ILAP and LLAP ( IC $_{50}$ of 43.4 and $53.7 \mu \mathrm{M}$, respectively) dropped to insignificant values when the penultimate $\mathrm{N}$-terminal Leu was replaced with Ile. Although many studies have identified food-derived DPP-IV inhibiting peptides, there is still a dearth of information on the role of the generally hydrophobic characters of the peptide in their transport through the intestinal epithelium and retention of their bioactivity once absorbed and distributed in the body.

\subsection{Amphipathicity in antimicrobial activity}

Cationic antimicrobial peptides (CAMPs) are net positively charged peptides of 12-50 amino acid residues, with approximately half of the structure being hydrophobic. CAMPs are naturally present in many organisms, where they play a non-specific defensive role against microbial infections (Hancock, 2001). The high content of lysine and arginine residues determines the cationic nature of the peptides. A combination of cationic patches and hydrophobic cores of CAMPs result in an amphipathicity and rearrangement of the peptides into specific $2 \mathrm{D}$ or $3 \mathrm{D}$ structures, which is crucial for antimicrobial activity. The cationic nature of CAMPs facilitates their interaction and movement through the anionic cell membrane of bacteria (Hancock, 2001), and their amphipathic nature enables them to adopt specific conformations that promote their penetration of the bacterial cell and prevents self-aggregation (Yin et al., 2012). Following a primary accumulation of CAMPs at the bacterial cell membrane, various mechanisms have been suggested for explaining their antimicrobial activity, including target of the cell membrane (transmembrane pore model, carpet pore model), cell wall synthesis, intracellular processes, or immune modulation (Kumar et al., 2018). Although the presence of both a hydrophobic core and a net positive charge on the peptide are crucial for this bioactivity, a threshold for both parameters exists above which the activity remains constant, but the hemolytic activity towards mammalian membrane increases (Dathe et al., 2001; Yin et al., 2012). For instance, Yin et al., (2012) observed that modifying the synthetic highly active CAMP 6K-F17 to the more hydrophobic $6 \mathrm{~K}-\mathrm{F} 17-4 \mathrm{~L}$ caused a decrease in antimicrobial activity and increase in hemolytic activity. The antimicrobial activity was however restored when positive charges were redistributed on the two termini of the same peptide, generating the peptide $3 \mathrm{~K}-\mathrm{F} 17-4 \mathrm{~L}-3 \mathrm{~K}$. On the other hand, the distribution of charges at the two edges of the native peptide, by generation of the CAMP 3K-F17-3K caused a significant drop in antimicrobial activity. The increased hydrophobic core was likely promoting the selfaggregating $\beta$-sheets structures at the bacterial membrane surface, therefore decreasing membrane penetration by the peptide. In a similar study, Dathe et al. (2001) observed a threshold value of +5 in the charge of CAMPs, above which a marked increase in hemolytic activity and decrease in permeabilization of the bacterial membrane was observed. Net charges higher that +5 were possibly causing such a powerful interaction of the peptide with the anionic lipids in the bacterial membrane bilayer that would prevent the peptide transport through the membrane and to reach the target sites. Interestingly, membrane permeability could then be restored by modification of the peptide hydrophobicity. Thus, the design of an optimally active CAMP (i.e., high antimicrobial and low hemolytic activities) is hinged on multiple factors such as peptide helicity, hydrophobicity of the core motifs, distribution of positive charges, reduction in aggregation, and the ability of the peptides to undergo oligomerization in the membrane (Yin et al., 2012).

Because of selectivity of interaction with components of the bacterial cell membrane and low affinity for mammalian membranes, CAMPs have attracted significant interest in recent years as possible substitutes for antibiotics. Also, the non-specific nature of their activity is favorable in preventing bacteria resistance to the peptides (Hancock, 2001). Despite the promising properties, only a few CAMPs have successfully been approved for use by the U.S. Food and Drug Administration, and some others are currently undergoing phase II and III clinical trials. Several challenges still need to be addressed, such as the susceptibility of the peptide to hydrolysis by digestive enzymes, their intrinsic toxicity, and discrepancy between activities in vitro and in vivo. For instance, the most active CAMP in vitro, polyphemusin, was found to be inactive in vivo, whereas some weakly active CAMPs in vitro displayed strong in vivo activities (Hancock, 2001). Currently, the role of peptide hydrophobicity in this instance is not apparent, although emerging work is focusing on using chemical and physical methods to improve the peptide stability by incorporating peptidomimetics and D-amino acids, cyclization, and use of targeted delivery systems (Kumar et al., 2018). Additionally, bioinformatic tools are rapidly evolving for organising large amounts of information in easily accessible databases. Further insights into structure-function relationship of CAMPs and new research directions were recently reviewed by Ahmed and 
Table 3. Food protein-derived bioactive peptides, with highlighted hydrophobic regions, and their respective bioactivities

\begin{tabular}{|c|c|c|c|}
\hline Sequence & Bioactivity & Experimental analysis & Reference \\
\hline $\begin{array}{l}\text { Phe-Asp-Ser-Gly-Pro-Ala-Gly-Val-Leu } \\
\text { Asn-Gly-Pro-Leu-GIn-Ala- } \\
\text { Gly-GIn-Pro-Gly-Glu-Arg }\end{array}$ & Antioxidant capacity & $\begin{array}{l}\text { In vitro analysis with human } \\
\text { lung fibroblasts }\end{array}$ & Mendis et al. (2005) \\
\hline $\begin{array}{l}\text { Gly-Val-Ser-Asn-Ala-Ala- } \\
\text { Val-Val-Ala-Gly-Gly-His } \\
\text { Asp-Ala-GIn-Glu-Phe-Lys-Arg }\end{array}$ & Antioxidant capacity & $\begin{array}{l}\text { In vitro and ex vivo analysis } \\
\text { on mouse fibroblasts }\end{array}$ & Coda et al. (2012) \\
\hline Tyr-Ala & Antioxidant capacity & $\begin{array}{l}\text { In vitro analysis using standard } \\
\text { methods involving ABTS, DPPH } \\
\text { and superoxide anion }\end{array}$ & Tang et al. (2010) \\
\hline Glu-Gln-Arg-Pro-Arg & Anticancer activity & $\begin{array}{l}\text { In vitro analysis in diverse normal } \\
\text { and cancer cell cultures }\end{array}$ & Kannana et al. (2010) \\
\hline $\begin{array}{l}\text { Gly-Gly-Arg-Lys-GIn-Gly-Gln- } \\
\text { His-Gln-GIn-Glu-Glu }\end{array}$ & Immunostimulating & $\begin{array}{l}\text { In vitro and in vivo analysis in cell } \\
\text { cultures and mice models }\end{array}$ & Gusa and Tani (2009) \\
\hline Val-Ile-Lys & $\begin{array}{l}\text { Anti-inflammatory } \\
\text { activity }\end{array}$ & $\begin{array}{l}\text { In vitro analysis in murine } \\
\text { macrophage cell lines }\end{array}$ & (Dia et al (2014) \\
\hline Tyr-Val-Pro-Gly-Pro & Anticancer activity & In vitro analysis on prostate cancer cells & Wu et al. (2018) \\
\hline $\begin{array}{l}\text { Ile-Pro } \\
\text { Leu-Pro }\end{array}$ & DPP-IV inhibition & In vitro analysis & Hatanaka et al. (2012) \\
\hline $\begin{array}{l}\text { Lys-Ala } \\
\text { Ala-Ala-Ala-Thr-Pro }\end{array}$ & DPP-IV inhibition & In vitro analysis & Gallego et al. (2014) \\
\hline $\begin{array}{l}\text { Arg-Trp } \\
\text { Arg-Trp-Arg-Trp } \\
\text { Arg-Trp-Arg-Trp-Arg-Trp } \\
\text { Arg-Trp-Arg-Trp-Arg-Trp-Arg-Trp } \\
\text { Arg-Trp-Arg-Trp-Arg-Trp- } \\
\text { Arg-Trp-Arg-Trp }\end{array}$ & Antimicrobial activity & $\begin{array}{l}\text { Increase in antimicrobial activity and } \\
\text { hemolysis of red blood cells with } \\
\text { increasing peptide chain length }\end{array}$ & Liu et al. (2007) \\
\hline $\begin{array}{l}\text { Val-GIn-Trp-Arg-Ile-Arg- } \\
\text { Val-Ala-Val-Ile-Arg-Lys }\end{array}$ & Antimicrobial activity & $\begin{array}{l}60 \mathrm{mg} / \mathrm{kg} \text { dose shown to be as } \\
\text { effective as vancomycin in rats } \\
\text { with Staphylococcus aureus }\end{array}$ & Wu et al. (2014) \\
\hline $\begin{array}{l}\text { Val-Leu-Leu-Val-Thr-Leu-Thr- } \\
\text { Arg-Leu-His-GIn-Arg-Gly-Val- } \\
\text { Ile-Tyr-Arg-Lys-Trp-Arg-His- } \\
\text { Phe-Ser-Gly-Arg-Lys-Tyr-Arg }\end{array}$ & Antimicrobial activity & $\begin{array}{l}\text { Antimicrobial studies with Escherichia } \\
\text { coli DH5 } \alpha \text {, Bacillus subtilis AZ54, } \\
\text { Staphylococcus aureus ATCC } 6538 \text { P } \\
\text { and Pseudomonas aeruginosa strains }\end{array}$ & Pane et al. (2017) \\
\hline $\begin{array}{l}\text { Glu-Lys-Glu-Arg-Glu-Arg-Gln } \\
\text { Lys-Arg-Gln-Lys-Tyr-Asp-Ile }\end{array}$ & ACE inhibition & $\begin{array}{l}\text { Oral administration to spontaneously } \\
\text { hypertensive rats (SHR) at a dose } \\
\text { of } 10 \mathrm{mg} / \mathrm{kg} \text { body weight }\end{array}$ & Katayama et al. (2008) \\
\hline Lys-Arg-Val-Ile-GIn-Try & ACE inhibition & $\begin{array}{l}\text { Oral administration to SHR at a } \\
\text { dose of } 10 \mathrm{mg} / \mathrm{kg} \text { body weight }\end{array}$ & $\begin{array}{l}\text { Muguruma et } \\
\text { al. (2009) }\end{array}$ \\
\hline $\begin{array}{l}\text { Arg-Pro-Arg } \\
\text { Lys-Ala-Pro-Val-Ala }\end{array}$ & ACE inhibition & $\begin{array}{l}\text { Oral administration to SHR at a } \\
\text { dose of } 1 \mathrm{mg} / \mathrm{kg} \text { body weight }\end{array}$ & Escudero et al. (2012) \\
\hline Pro-Thr-Pro-Val-Pro & & & \\
\hline
\end{tabular}

Hammami (2018) and Kumar et al. (2018).

\subsection{Bile acid binding capacity}

Endogenous cholesterol level is regulated by harmonizing the absorption of food-derived cholesterol and hepatic cholesterol biosynthesis. The absorption of dietary cholesterol is mediated by its solubilization in bile acids, which triggers the formation of micelles that are easily absorbed in the small intestine (Wilson and Rudel, 1994). Bile acid binding peptides have the potential to inhibit cholesterol absorption in the intestinal cells by dimin- 
ishing bile acid availability and the subsequent incorporation of cholesterol into absorbable micelles. Bile acid binding peptides can also increase bile acid excretion, thereby inhibiting enterohepatic circulation of bile acids and increasing metabolism of hepatic cholesterol to replenish the excreted bile acids (Boachie et al., 2018). Interestingly, Choi et al. (2002) identified a 47-amino acid residue region subunit A1a that appeared to be primarily involved in the bile acid-binding property of soy glycinin. Further analysis led to the identification of an 8-amino acid hydrophobic region (Val-Ala-Trp-Trp-Met-Tyr; also known as soystatin), which is responsible for the bile acid-binding property. Further studies demonstrated that the bile acid-binding by soystatin was translated in vivo in rats (Nagaoka et al., 2010). Based on soystatin, Ito et al. (2018) used in silico analysis, where each amino acid residue was replaced, to demonstrate the additional role of electrostatic properties in bile acid binding. Bile acids are amphipathic and, similar to CAMPs, peptides with hydrophobic and cationic characters are better positioned to respectively interact with the hydrophobic and hydrophilic regions of bile acids. Moreover, considerable attention should be given to the peptide conformation and 3-dimensional structure. For instance, a two-fold increase in bile acid-binding capacity was observed when a chicken meat protein hydrolysate was converted to plastein aggregate, even when the samples have a similar amino acid profiles. This effect is attributed to peptide aggregation and subsequent increase in surface hydrophobicity as a result of plastein aggregate formation (Udenigwe et al., 2015). Furthermore, plastein isolation from the crude reaction product resulted in higher mean particle size, surface hydrophobicity, and hydrophobic-to-hydrophilic amino acid ratio, leading to a higher binding capacity and stronger affinity (lower dissociation constant, $\mathrm{Kd}$ ) of the aggregated peptides for sodium deoxycholate (Mohan and Udenigwe, 2015). Another hydrophobic peptide, Ile-Ala-ValPro-Gly-Glu-Val-Ala, derived from pepsin hydrolysis of $11 \mathrm{~S}$ globulin was also reported to bind cholic and deoxycholic acids in vitro (Pak et al., 2005), whereas Leu-Pro-Tyr-Pro-Arg (from soybean glycinin) and His-Ile-Arg-Leu (from $\beta$-lactoglobulin) decreased serum cholesterol by $>25 \%$ and $17 \%$, respectively after two days of oral administration to mice (Yoshikawa et al., 2000). Although further research is needed to elucidate in vivo mechanism of bile acid-binding peptides, current evidence indicates the dominance of hydrophobic residues in the peptide structure and supports their important role in the bioactivity.

\subsection{Antioxidant capacity}

Oxidation is an important process that leads to the generation of free radicals and reactive oxygen species, which are actively involved in physiological processes in the human body. However, excessive oxidation can be damaging to cells and food products. For instance, lipid peroxidation generates unwanted products including aldehydes, peroxides, and ketones (Ayala et al., 2014). Oxidative stress occurs when endogenous antioxidants are overwhelmed by prooxidants, and this can result in disease conditions such as diabetes, arthritis, inflammation, and cancer (Huang et al., 2005). Peptides are known to have strong antioxidant capacity. A study suggested that typical structural characteristics of antioxidant peptides include the presence of hydrophobic amino acid residues Leu or Val at the N-terminus and the presence of Pro, His or Tyr in the sequence (Sabeena Farvin et al. 2010). According to Zou et al. (2016), Trp, Phe, Val, Ile, Gly, Lys, and Pro are the most established hydrophobic amino acids associated with antioxidant activities. Tian et al. (2015) demonstrated that the presence of hydrophobic Trp residues in peptides contributes to high antioxidant capacity. Likewise, Pro residue is thought to alter the secondary structure of peptides, thereby enhancing the interaction of the amino acid residues of peptide and their antioxidative properties (Zou et al., 2016). Additionally, Leu and the motifs Ser-Leu, Thr-Leu and Pro-Leu, especially when located at the N- and C- terminal, are known to enhance the antioxidant activities of peptides, with the C-terminus being more influential in determining the activity (Li and Li 2013). Moreover, hydrophobic Phe and Tyr residues of peptides have aromatic rings capable of reacting with hydroxyl radical to form stable hydroxylated derivatives (Pownall et al., 2010). Apart from this mechanism, hydrophobic residues and motifs are thought to facilitate the interaction of antioxidant peptides with hydrophobic, biological targets of oxidation. A chemometric study reported a positive relationship between the total content of hydrophobic amino acids of food protein hydrolysates and their capacity to scavenge a hydrophobic synthetic radical and hydrogen peroxide (Udenigwe and Aluko, 2011). Despite the experimental evidence to support this relationship, in most cases, the particular role of hydrophobicity in promoting the antioxidant capacity of peptides is still not clear. Table 3 shows a list of some hydrophobic, food protein-derived peptides and their respective in vitro and in vivo bioactivities.

\section{Conclusion}

Hydrophobicity is an important feature of peptides that determines their interaction with several physiological targets and their bioactivities. Peptide hydrophobicity can be affected by the degree of hydrolysis, processing conditions, type of protease, average hydrophobicity value of protein precursors, and sequence of hydrophobic amino acid residues in the peptide chain. Particular proteases (e.g. Alcalase, thermolysin) have high specificity in cleaving hydrophobic amino acid residues in food proteins during the generation of bioactive peptides, with a concomitant release of hydrophobic peptides and amino acids and increase in the bitterness score. Hydrophobicity is also demonstrated to influence peptide self-assembly, emulsifying capacity, bitterness property and other properties, including biostability and potentially bioavailability. Thus, the ability of bioactive peptides to escape proteolytic degradation and be transported across the intestinal barrier in humans may be enhanced by modifying peptide structural features, including hydrophobicity.

\section{Acknowledgments}

We acknowledge the support of the Natural Sciences and Engineering Research Council of Canada (NSERC), reference number RGPIN-2018-06839. Cette recherche a été financée par le Conseil de recherches en sciences naturelles et en génie du Canada (CRSNG), numéro de référence RGPIN- 2018-06839.

\section{Conflict of interest}

There is no conflict of interest involved in this article.

\section{References}

Agyei, D., Acquah, C., Tan, K.X., Hii, H.K., Rajendran, S.R.C.K., Udenigwe, C.C., and Danquah, M.K. (2017). Prospects in the use of aptamers for 
characterizing the structure and stability of bioactive proteins and peptides in food. Anal. Bioanal. Chem. 410: 297-306. doi:10.1007/ s00216-017-0599-9.

Ahmed, T.A.E., and Hammami, R. (2018). Recent insights into structurefunction relationships of antimicrobial peptides. J. Food Biochem. 2018: e12546. doi:10.1111/jfbc.12546.

Al-Shamsi, K.A., Mudgil, P., Hassan, H.M., and Maqsood, S. (2018). Camel milk protein hydrolysates with improved technofunctional properties and enhanced antioxidant potential in in vitro and in food model systems. J. Dairy. Sci. 101: 47-60. doi:10.3168/jds.2017-13194.

Alemán, A., Gómez-Guillén, M.C., and Montero, P. (2013). Identification of ace-inhibitory peptides from squid skin collagen after in vitro gastrointestinal digestion. Food Res. Int. 54: 790-795. doi:10.1016/j. foodres.2013.08.027.

Arulmozhiraja, S., Matsuo, N., Ishitsubo, E., Okazaki, S., Shimano, H., and Tokiwa, H. (2016). Comparative binding analysis of dipeptidyl peptidase IV (DPP-4) with antidiabetic drugs -an ab initio fragment molecular orbital study. PLoS ONE 11: 1-15. doi:10.1371/journal. pone. 0166275 .

Ayala, A., Muñoz, M.F., and Argüelles, S. (2014). Lipid peroxidation: production, metabolism, and signaling mechanisms of malondialdehyde and 4-hydroxy-2-nonenal. Oxid. Med. Cell. Longev. 2014: 360438. doi:10.1155/2014/360438.

Bejjani, S., and Wu, J. (2013). Transport of IRW, an ovotransferrin-derived antihypertensive peptide, in human intestinal epithelial Caco-2 cells. J. Agric. Food Chem. 61: 1487-1492. doi:10.1021/jf302904t.

Boachie, R., Yao, S., and Udenigwe, C.C. (2018). Molecular mechanisms of cholesterol-lowering peptides derived from food proteins. Curr. Opin. Food Sci. 20: 58-63. doi:10.1016/j.cofs.2018.03.006.

Chen, L., Chen, J., Yu, L., and Wu, K. (2016). Improved emulsifying capabilities of hydrolysates of soy protein isolate pretreated with high pressure microfluidization. LWT - Food Sci. Technol. 69: 1-8. doi:10.1016/J.LWT.2016.01.030.

Cheung, H.S., Wang, F.L., Ondetti, M.A., Sabo, E.F., and Cushman, D.W. (1980). Binding of peptide substrates and inhibitors of angiotensinconverting enzyme. Importance of the $\mathrm{COOH}$-terminal dipeptide sequence. J. Biol. Chem. 255: 401-407.

Cheung, I.W.Y., Nakayama, S., Hsu, M.N.K., Samaranayaka, A.G.P., and LiChan, E.C.Y. (2009). Angiotensim-I converting enzyme inhibitory activity of hydrolysates from oat (Avena sativa) proteins by in silico and in vitro analyses. J. Agric. Food Chem. 57: 9234-9242. doi:10.1021/ jf9018245.

Choi, S.-K., Adachi, M., and Utsumi, S. (2002). Identification of the bile acid-binding region in the soy glycinin A1ab1b subunit. Biosci. Biotech. Biochem. 66: 2395-2401. doi:10.1271/bbb.66.2395.

Chua, H.-L., Jois, S., Sim, M.-K., and Go, M.-L. (2004). Transport of angiotensin peptides across the Caco-2 monolayer. Peptides 25: 1327-1338. doi:10.1016/j.peptides.2004.06.009.

Coda, R., Rizzello, C.G., Pinto, D., and Gobbetti, M. (2012). Selected lactic acid bacteria synthesize antioxidant peptides during sourdough fermentation of cereal flours. Appl Environ. Microbiol. 78: 1087-1096. doi:10.1128/AEM.06837-11.

Cornette, J.L., Cease, K.B., Margalit, H., Spouge, J.L., Berzofsky, J.A., and DeLisi, C. (1987). Hydrophobicity scales and computational techniques for detecting amphipathic structures in proteins. J. Mol. Biol. 195: 659-685. doi:10.1016/0022-2836(87)90189-6.

Cui, H., Muraoka, T., Cheetham, A.G., and Stupp, S.I. (2009). Self-Assembly of giant peptide nanobelts. Nano Lett. 9: 945-951. doi:10.1021/ nl802813f.

Dathe, M., Nikolenko, H., Meyer, J., Beyermann, M., and Bienert, M. (2001). Optimization of the antimicrobial activity of magainin peptides by modification of charge. FEBS Lett. 501: 146-150. doi:10.1016/S00145793(01)02648-5.

Deming, T.J. (2005). Polypeptide hydrogels via a unique assembly mechanism. Soft Matter 1: 28-35. doi:10.1039/b500307e.

Dia, V.P., Bringe, N.A., and de Mejia, E.G. (2014). Peptides in pepsin-pancreatin hydrolysates from commercially available soy products that inhibit lipopolysaccharide-induced inflammation in macrophages. Food Chem. 152: 423-431. doi:10.1016/J.FOODCHEM.2013.11.155.

Doll, T.A.P.F., Raman, S., Dey, R., and Burkhard, P. (2013). Nanoscale assemblies and their biomedical applications. J. Royal Soc. Interface 10:
20120740-20120740. doi:10.1098/rsif.2012.0740.

Eisenberg, D., Schwarz, E., Komaromy, M., and Wall, R. (1984). Analysis of membrane and surface protein sequences with the hydrophobic moment plot. J. Mol. Biol. 179: 125-142. doi:10.1016/00222836(84)90309-7.

Escudero, E., Mora, L., Fraser, P.D., Aristoy, M.-C., Arihara, K., and Toldrá, F. (2013). Purification and Identification of antihypertensive peptides in Spanish dry-cured ham. J. Proteom. 78: 499-507. doi:10.1016/J. JPROT.2012.10.019.

Escudero, E., Toldrá, F., Sentandreu, M.A., Nishimura, H., and Arihara, K. (2012). Antihypertensive activity of peptides identified in the in vitro gastrointestinal digest of pork meat. Meat Sci. 91: 382-384. doi:10.1016/J.MEATSCI.2012.02.007.

Fekete, Á., Givens, D., and Lovegrove, J. (2015). Casein-derived lactotripeptides reduce systolic and diastolic blood pressure in a meta-analysis of randomised clinical trials. Nutrients 7: 659-681. doi:10.3390/ nu7010659.

Fernández-Tomé, S., Sanchón, J., Recio, I., and Hernández-Ledesma, B. (2018). Transepithelial transport of lunasin and derived peptides: Inhibitory effects on the gastrointestinal cancer cells viability. J. Food Compos. Anal. 68: 101-110. doi:10.1016/J.JFCA.2017.01.011.

Fu, Y., Young, J.F., Rasmussen, M.K., Dalsgaard, T.K., Lametsch, R., Aluko, R.E., and Therkildsen, M. (2016). Angiotensin I-converting enzymeinhibitory peptides from bovine collagen: insights into inhibitory mechanism and transepithelial transport. Food Res. Int. 89: 373381. doi:10.1016/J.FOODRES.2016.08.037.

Gallego, M., Aristoy, M.-C., and Toldrá, F. (2014). Dipeptidyl peptidase IV inhibitory peptides generated in Spanish dry-cured ham. Meat Sci. 96: 757-761. doi:10.1016/J.MEATSCI.2013.09.014.

Ganesan, S.J., and Matysiak, S. (2016). Interplay between the hydrophobic effect and dipole interactions in peptide aggregation at interfaces. Phys. Chem. Chem. Phys. 18: 2449-58. doi:10.1039/c5cp05867h.

Gusa, S.E., and Tani, H.O. (2009). Characterization of a cellular immunostimulating peptide from a soybean protein fraction digested with peptidase R. J. Nutr. Sci. Vitaminol. 55: 428-433. doi:10.3177/ jnsv.55.428.

Hall, F.G., Jones, O.G., O'Haire, M.E., and Liceaga, A.M. (2017). Functional properties of tropical banded cricket (Gryllodes sigillatus) protein hydrolysates. Food Chem. 224: 414-422. doi:10.1016/j.foodchem.2016.11.138.

Hancock, R.E. (2001). Cationic peptides: Effectors in innate immunity and novel antimicrobials. Lancet Infect. Dis. 1: 156-164. doi:10.1016/ S1473-3099(01)00092-5.

Harnedy, P.A., O'Keeffe, M.B., and Fitzgerald, R.J. (2015). Purification and identification of dipeptidyl peptidase (DPP) IV inhibitory peptides from the macroalga Palmaria palmata. Food Chem. 172: 400-406. doi:10.1016/j.foodchem.2014.09.083.

Hatanaka, T., Inoue, Y., Arima, J., Kumagai, Y., Usuki, H., Kawakami, K., Kimura, M., and Mukaihara, T. (2012). Production of dipeptidyl peptidase IV inhibitory peptides from defatted rice bran. Food Chem. 134: 797-802. doi:10.1016/j.foodchem.2012.02.183.

Heinz Ney, K. (1979). Bitterness of peptides: amino acid composition and chain length. ACS Simposium Series 115: 149-173. doi:10.1021/bk1979-0115.ch006.

Hopp, T.P., and Woods, K.R. (1983). A computer program for predicting protein antigenic determinants. Mol. Immunol. 20: 483-489. doi:10.1016/0161-5890(83)90029-9.

Huang, D., Boxin, O., and Prior, R.L. (2005). The chemistry behind antioxidant capacity assays. J. Agric. Food Chem. 53: 1841-1856. doi:10.1021/JF030723C.

Humiski, L.M., and Aluko, R.E. (2007). Physicochemical and bitterness properties of enzymatic pea protein hydrolysates. J. Food Sci. 72: S605-S611. doi:10.1111/j.1750-3841.2007.00475.x.

Hutchinson, J.A., Burholt, S., and Hamley, I.W. (2017). Peptide hormones and lipopeptides: from self-assembly to therapeutic applications. J. Pept. Sci. 23: 82-94. doi:10.1002/psc.2954.

Ito, M., Shimizu, K., and Honda, H. (2018). Searching for high-binding peptides to bile acid for inhibition of intestinal cholesterol absorption using principal component analysis. J. Biosci. Bioeng. doi:10.1016/j. jbiosc.2018.08.006.

Iwaniak, A., Hrynkiewicz, M., Bucholska, J., Minkiewicz, P., and Darewicz, 
M. (2018). Understanding the nature of bitter-taste di- and tripeptides derived from food proteins based on chemometric analysis. J. Food Biochem. 2018: e12500. doi:10.1111/jfbc.12500.

Kang, M.-G., Yi, S.-H., and Lee, J.-S. (2013). Production and characterization of a new $\alpha$-glucosidase inhibitory peptide from Aspergillus oryzae N159-1. Mycobiology 41: 149-154. doi:10.5941/ MYCO.2013.41.3.149.

Kannana, A., Hettiarachchy, N.S., Lay, J.O., and Liyanage, R. (2010). Human cancer cell proliferation inhibition by a pentapeptide isolated and characterized from rice bran. Peptides 31: 1629-1634. doi:10.1016/j. peptides.2010.05.018.

Katayama, K., Anggraeni, H.E., Mori, T., Ahhmed, A.M., Kawahara, S., Sugiyama, M., Nakayama, T., and Muguruma, M. (2008). Porcine skeletal muscle troponin is a good source of peptides with angiotensin-i converting enzyme inhibitory activity and antihypertensive effects in spontaneously hypertensive rats. J. Agric. Food Chem. 56: 355-360. doi:10.1021/jf071408j.

Kim, W., and Hecht, M.H. (2006). Generic hydrophobic residues are sufficient to promote aggregation of the Alzheimer's Abeta42 peptide. Proc. Natl. Acad. Sci. USA 103: 15824-29. doi:10.1073/ pnas.0605629103.

Kohl, S., Behrens, M., Dunkel, A., Hofmann, T., and Meyerhof, W. (2012). Amino acids and peptides activate at least five members of the human bitter taste receptor family. J. Agric. Food Chem. 61: 53-60. doi:10.1021/jf303146h.

Kumar, P., Kizhakkedathu, J.N., and Straus, S.K. (2018). Antimicrobial peptides: Diversity, mechanism of action and strategies to improve the activity and biocompatibility in vivo. Biomolecules 8: 4. doi:10.3390/ biom8010004

Kyte, J., and Doolittle, R.F. (1982). A simple method for displaying the hydropathic character of a protein. J. Mol. Biol. 157: 105-132. doi:10.1016/0022-2836(82)90515-0.

Lam, R.S.H., and Nickerson, M.T. (2013). Food proteins: A review on their emulsifying properties using a structure-function approach. Food Chem. 141: 975-984. doi:10.1016/j.foodchem.2013.04.038.

Li, Y.-W., and Li, B. (2013). Characterization of structure-antioxidant activity relationship of peptides in free radical systems using QSAR models: Key sequence positions and their amino acid properties. J. Theor. Biol. 318: 29-43. doi:10.1016/j.jtbi.2012.10.029.

Liu, R., Zhou, L., Zhang, Y., Sheng, N.J., Wang, Z.K., Wu, T.Z., Wang, X.Z., and Wu, H. (2017). Rapid identification of dipeptidyl peptidase-IV (dppIV) inhibitory peptides from ruditapes philippinarum hydrolysate. Molecules 22(10): 1714. doi:10.3390/molecules22101714.

Liu, Z., Brady, A., Young, A., Rasimick, B., Chen, K., Zhou, C., and Kallenbach, N.R. (2007). Length effects in antimicrobial peptides of the (RW)n series. Antimicrob. Agents Chemother. 51: 597-603. doi:10.1128/ AAC.00828-06.

Majumder, K., and Wu, J. (2009). Angiotensin i converting enzyme inhibitory peptides from simulated in vitro gastrointestinal digestion of cooked eggs. J. Agric. Food Chem. 57: 471-477. doi:10.1021/ jf8028557.

Mandal, D., Nasrolahi Shirazi, A., and Parang, K. (2014). Self-assembly of peptides to nanostructures. Org. Biomol. Chem. 12: 3544-3561. doi:10.1039/C4OB00447G.

Meli, M., Morra, G., and Colombo, G. (2008). Investigating the mechanism of peptide aggregation: insights from mixed Monte Carlo-molecular dynamics simulations. Biophys. J. 94: 4414-26. doi:10.1529/biophysj.107.121061

Mendis, E., Rajapakse, N., Byun, H.-G., and Kim, S.-K. (2005). Investigation of jumbo squid (Dosidicus gigas) skin gelatin peptides for their in vitro antioxidant effects. Life Sci. 77: 2166-2178. doi:10.1016/j Ifs.2005.03.016.

Miguel, M., Recio, I., Gómez-Ruiz, J.A., Ramos, M., and López-Fandiño, R. (2004). Angiotensin I-converting enzyme inhibitory activity of peptides derived from egg white proteins by enzymatic hydrolysis. J. Food Protect. 67: 1914-1920. doi:10.4315/0362-028X-67.9.1914.

Miñones Conde, J., and Rodríguez Patino, J.M. (2007). The effect of enzymatic treatment of a sunflower protein isolate on the rate of adsorption at the air-water interface. J. Food Eng. 78: 1001-1009. doi:10.1016/J.JFOODENG.2005.12.013

Mohan, A., and Udenigwe, C.C. (2015). Towards the design of hypolipi- daemic peptides: Deoxycholate binding affinity of hydrophobic peptide aggregates of casein plastein. J. Funct. Foods 18: 129-136. doi:10.1016/j.jff.2015.06.064.

Mojica, L., and de Mejía, E.G. (2016). Optimization of enzymatic production of anti-diabetic peptides from black bean (Phaseolus vulgaris L.) proteins, their characterization and biological potential. Food Funct. 7: 713-727. doi:10.1039/C5FO01204J.

Mojica, L., Luna-Vital, D.A., and González de Mejía, E. (2017). Characterization of peptides from common bean protein isolates and their potential to inhibit markers of type-2 diabetes, hypertension and oxidative stress. J. Sci. Food Agric. 97: 2401-2410. doi:10.1002/jsfa.8053.

Moorthy, N.S.H.N., Ramos, M.J., and Fernandes, P.A. (2011). Structural analysis of $\alpha$-glucosidase inhibitors by validated QSAR models using topological and hydrophobicity based descriptors. Chemom. Intell. Lab Syst. 109: 101-112. doi:10.1016/j.chemolab.2011.02.010.

Muguruma, M., Ahhmed, A.M., Katayama, K., Kawahara, S., Maruyama, M., and Nakamura, T. (2009). Identification of pro-drug type ACE inhibitory peptide sourced from porcine myosin B: Evaluation of its antihypertensive effects in vivo. Food Chem. 114: 516-522. doi:10.1016/j.foodchem.2008.09.081.

Murray, N.M., O’Riordan, D., Jacquier, J.-C., O'Sullivan, M., Holton, T.A., Wynne, K., Robinson, R.C., Barile, D., Nielsen, S.D., and Dallas, D.C. (2018). Peptidomic screening of bitter and nonbitter casein hydrolysate fractions for insulinogenic peptides. J. Dairy Sci. 101: 28262837. doi:10.3168/jds.2017-13853

Nagaoka, S., Nakamura, A., Shibata, H., and Kanamaru, Y. (2010). Soystatin (VAWWMY), a novel bile acid-binding peptide, decreased micellar solubility and inhibited cholesterol absorption in rats. Biosci. Biotechnol. Biochem. 74: 1738-1741. doi:10.1271/bbb.100338.

Ohsawa, K., Satsu, H., Ohki, K., Enjoh, M., Takano, T., and Shimizu, M. (2008). Producibility and digestibility of antihypertensive $\beta$-casein tripeptides, Val-Pro-Pro and Ile-Pro-Pro, in the gastrointestinal tract: analyses using an in vitro model of mammalian gastrointestinal digestion. J. Agric. Food Chem. 56: 854-858. doi:10.1021/jf072671n.

Ohyama, S., Ishibashi, N., Tamura, M., Nishizaki, H., and Okai, H. (1988) Synthesis of bitter peptides composed of aspartic acid and glutamic acid.Agric. Biol. Chem. 52: 871-872. doi:10.1080/00021369.1988.1 0868747.

Pak, V.V., Koo, M.S., Kasymova, T.D., and Kwon, D.Y. (2005). Isolation and identification of peptides from soy 11S-globulin with hypocholesterolemic activity. Chem. Nat. Compd. 41: 710-714. doi:10.1007/ s10600-006-0017-6.

Pane, K., Durante, L., Crescenzi, O., Cafaro, V., Pizzo, E., Varcamonti, M. Zanfardino, A., Izzo, V., Di Donato, A., and Notomista, E. (2017). Antimicrobial potency of cationic antimicrobial peptides can be predicted from their amino acid composition: Application to the detection of "cryptic" antimicrobial peptides. J. Theor. Biol. 419: 254-265. doi:10.1016/J.JTBI.2017.02.012.

Pauletti, G.M., Gangwar, S., Siahaan, T.J., Aubé, J., and Borchardt, R.T. (1997). Improvement of oral peptide bioavailability: Peptidomimetics and prodrug strategies. Adv. Drug Deliv. Rev. 27: 235-256. doi:10.1016/S0169-409X(97)00045-8.

Power, O., Nongonierma, A.B., Jakeman, P., and FitzGerald, R.J. (2014). Food protein hydrolysates as a source of dipeptidyl peptidase IV inhibitory peptides for the management of type 2 diabetes. Proc. Nutr. Soc. 73: 34-46. doi:10.1017/S0029665113003601.

Pownall, T.L., Udenigwe, C.C., and Aluko, R.E. (2010). Amino acid composition and antioxidant properties of pea seed (Pisum sativum L.) enzymatic protein hydrolysate fractions. J. Agric. Food Chem. 58 4712-4718. doi:10.1021/jf904456r.

Qi, M., Hettiarachchy, N.S., and Kalapathy, U. (1997). Solubility and emulsifying properties of soy protein isolates modified by pancreatin. J. Food Sci. 62: 1110-1115. doi:10.1111/j.1365-2621.1997.tb12224.x.

Rani, S., Pooja, K., and Pal, G.K. (2018). Exploration of rice protein hydroIysates and peptides with special reference to antioxidant potential: Computational derived approaches for bio-activity determination. Trends Food Sci. Technol. 80: 61-70. doi:10.1016/J.TIFS.2018.07.013.

Sabeena Farvin, K.H., Baron, C.P., Nielsen, N.S., Otte, J., and Jacobsen, C. (2010). Antioxidant activity of yoghurt peptides: Part 2 - Characterisation of peptide fractions. Food Chem. 123: 1090-1097. doi:10.1016/j.foodchem.2010.05.029. 
Saiga, A., Okumura, T., Makihara, T., Katsuda, S.I., Morimatsu, F., and Nishimura, T. (2006). Action mechanism of an angiotensin I-converting enzyme inhibitory peptide derived from chicken breast muscle. J. Agric. Food Chem. 54: 942-945. doi:10.1021/jf0508201.

Sánchez, A., and Vázquez, A. (2017). Bioactive peptides: A review. Food Qual. Saf. 1: 29-46. doi:10.1093/fqsafe/fyx006.

Seo, W.H., Lee, H.G., and Baek, H.H. (2007). Evaluation of bitterness in enzymatic hydrolysates of soy protein isolate by taste dilution analysis. J. Food Sci. 73: S41-S46. doi:10.1111/j.1750-3841.2007.00610.x.

Shimizu, M., Tsunogai, M., and Arai, S. (1997). Transepithelial transport of oligopeptides in the human intestinal cell, Caco-2. Peptides 18: 681-687. doi:10.1016/S0196-9781(97)00002-8.

Stefano, E.D.i., Oliviero, T., and Udenigwe, C.C. (2018). Functional significance and structure - activity relationship of food-derived a -glucosidase inhibitors. Curr. Opin. Food Sci. 20: 7-12.

Tang, X., He, Z., Dai, Y., Xiong, Y.L., Xie, M., and Chen, J. (2010). Peptide Fractionation and Free Radical Scavenging Activity of Zein Hydrolysate. J. Agric. Food Chem. 58: 587-593. doi:10.1021/jf9028656.

Tian, M., Fang, B., Jiang, L., Guo, H., Cui, J., and Ren, F. (2015). Structureactivity relationship of a series of antioxidant tripeptides derived from $\beta$-lactoglobulin using QSAR modeling. Dairy Sci. Technol. 95: 451-463. doi:10.1007/s13594-015-0226-5.

Tsumura, K. (2009). Improvement of the physicochemical properties of soybean proteins by enzymatic hydrolysis. Food Sci. Technol. Res. 15: 381-388. doi:10.3136/fstr.15.381.

Udenigwe, C.C. (2014). Bioinformatics approaches, prospects and challenges of food bioactive peptide research. Trends Food Sci. Technol. 36: 137-143. doi:10.1016/j.tifs.2014.02.004.

Udenigwe, C.C., and Aluko, R.E. (2012). Food protein-derived bioactive peptides: production, processing, and potential health benefits. J. Food Sci. 77: R11-R24. doi:10.1111/j.1750-3841.2011.02455.x.

Udenigwe, C.C., and Aluko, R.E. (2011). Chemometric analysis of the amino acid requirements of antioxidant food protein hydrolysates. Int. J. Mol. Sci. 12: 3148-3161. doi:https://dx.doi.org/10.3390/ ijms12053148.

Udenigwe, C.C., Gong, M., and Wu, S. (2013). In silico analysis of the large and small subunits of cereal RuBisCO as precursors of cryptic bioactive peptides. Process Biochem. 48: 1794-1799. doi:10.1016/j. procbio.2013.08.013.

Udenigwe, C.C., Mohan, A., and Wu, S. (2015). Peptide aggregation during plastein reaction enhanced bile acid-binding capacity of enzymatic chicken meat hydrolysates. J. Food Biochem. 39: 344-348. doi:10.1111/jfbc.12139.

Upadhyaya, J., Pydi, S.P., Singh, N., Aluko, R.E., and Chelikani, P. (2010). Bitter taste receptor T2R1 is activated by dipeptides and tripeptides. Biochem. Biophys. Res. Commun. 398: 331-335. doi:10.1016/j. bbrc.2010.06.097.

Vij, R., Reddi, S., Kapila, S., and Kapila, R. (2016). Transepithelial transport of milk derived bioactive peptide VLPVPQK. Food Chem. 190: 681688. doi:10.1016/j.foodchem.2015.05.121.

Wang, B., and Li, B. (2017). Effect of molecular weight on the transepithelial transport and peptidase degradation of casein-derived peptides by using Caco-2 cell model. Food Chem. 218: 1-8. doi:10.1016/j. foodchem.2016.08.106.

Wilson, M.D., and Rudel, L.L. (1994). Review of cholesterol absorption with emphasis on dietary and biliary cholesterol. J. Lipid Res. 35: 943-955.

Wimley, W.C., and White, S.H. (1996). Experimentally determined hydrophobicity scale for proteins at membrane interfaces. Nat. Struct. Mol. Biol. 3: 842-848. doi:10.1038/nsb1096-842.

Wolfenden, R., Geselowitz, A., Lesser, G., Lee, R., and Zehfus, M. (1983). Hydrophobicity of amino acid residues in globular proteins. Science 222: 1087-1093. doi:10.1126/science.6359416.

$\mathrm{Wu}$, J., and Aluko, R.E. (2007). Quantitative structure-activity relationship study of bitter di- and tri-peptides including relationship with angiotensin I-converting enzyme inhibitory activity. J. Pept. Sci. 13: 63-69. doi:10.1002/psc.800.

Wu, X., Wang, Z., Li, X., Fan, Y., He, G., Wan, Y., Yu, C., Tang, J., Li, M., Zhang, X., Zhang, H., Xiang, R., Pan, Y., Liu, Y., Lu, L., and Yang, L. (2014). In vitro and in vivo activities of antimicrobial peptides developed using an amino acid-based activity prediction method. Antimicrob. Agents Chemother. 58: 5342-5349. doi:10.1128/aac.02823-14.

Wu, Z.-Z., Ding, G.-F., Huang, F.-F., Yang, Z.-S., Yu, F.-M., Tang, Y.-P., Jia, Y.L., Zheng, Y.Y., and Chen, R. (2018). Anticancer activity of Anthopleura anjunae oligopeptides in prostate cancer DU-145 cells. Mar. Drugs 16: 125 . doi:10.3390/md16040125.

Xie, N., Wang, B., Jiang, L., Liu, C., and Li, B. (2015). Hydrophobicity exerts different effects on bioavailability and stability of antioxidant peptide fractions from casein during simulated gastrointestinal digestion and Caco-2 cell absorption. Food Res. Int. 76: 518-526. doi:10.1016/j. foodres.2015.06.025.

Yang, Y.-J., He, H.-Y., Wang, F.-Z., Ju, X.-R., Yuan, J., Wang, L.-F., Aluko, R., and He, R. (2017). Transport of angiotensin converting enzyme and renin dual inhibitory peptides LY, RALP and TF across Caco- 2 cell monolayers. J. Funct. Foods 35: 303-314. doi:10.1016/j.jff.2017.05.053.

Yao, S., Agyei, D., and Udenigwe, C.C. (2018). Structural basis of bioactivity of food peptides in promoting metabolic health. Adv. Food Nutr. Res. 84: 145-181. doi:10.1016/bs.afnr.2017.12.002.

Yin, L.M., Edwards, M.A., Li, J., Yip, C.M., and Deber, C.M. (2012). Roles of hydrophobicity and charge distribution of cationic antimicrobial peptides in peptide-membrane interactions. J. Biol. Chem. 287: 77387745. doi:10.1074/jbc.m111.303602.

Yoshikawa, M., Fujita, H., Matoba, N., Takenaka, Y., Yamamoto, T., Yamauchi, R., Tsuruki, K., and Takahata, K. (2000). Bioactive peptides derived from food proteins preventing lifestyle-related diseases. BioFactors 12: 143-146. doi:10.1002/biof.5520120122.

Zhang, C., Alashi, A.M., Singh, N., Liu, K., Chelikani, P., and Aluko, R.E. (2018). Beef protein-derived peptides as bitter taste receptor T2R4 blockers. J. Agric. Food Chem. 66: 4902-4912. doi:10.1021/acs. jafc.8b00830.

Zhou, P., Deng, L., Wang, Y., Lu, J.R., and Xu, H. (2016). Different nanostructures caused by competition of intra- and inter- $\beta$-sheet interactions in hierarchical self-assembly of short peptides. J. Colloid Interface Sci. 464: 219-228. doi:10.1016/j.jcis.2015.11.030.

Zou, T.-B., He, T.-P., Li, H.-B., Tang, H.-W., and Xia, E.-Q. (2016). The structure-activity relationship of the antioxidant peptides from natural proteins. Molecules 21: 72. doi:10.3390/molecules21010072. 